\title{
Versatility of Photosensitizers in Dye-Sensitized Solar Cells (DSSCs)
}

\author{
Anis Kharul Nada Mohd Yusuf 1(D), Suzaliza Mustafar 1,*(D), Ma. Leah Borines 2(D), Etty Nurlia \\ Kusumawati $^{3}$ (D), Norhayati Hashim 1 (D)
}

1 Department of Chemistry, Faculty of Science and Mathematics, Universiti Pendidikan Sultan Idris, 35900 Tanjong Malim, Perak, Malaysia; aniskharulnada@gmail.com (A.K.N.M.Y.), $\quad$ suzaliza@fsmt.upsi.edu.my (S.M.), norhayati.hashim@fsmt.upsi.edu.my (N.H.);

2 Department of Chemistry, University of Connecticut, 55 North Eagleville Road, Unit 3060, Storrs, Connecticut, U.S.A.; ma._leah.borines@uconn.edu (M.L.B.);

3 Chemistry Course, Faculty of Science and Engineering, Iwate University, 4-3-5, Morioka, Iwate 020-8551, Japan; etty01@iwate-u.ac.jp (E.N.K.);

* Correspondence: suzaliza@ fsmt.upsi.edu.my (S.M.);

Scopus Author ID 56607376300

Received: 1.11.2021; Revised: 2.12.2021; Accepted: 5.12.2021; Published: 13.12.2021

\begin{abstract}
Because of their scientific relevance in the field of energy conversion, dye-sensitized solar cells (DSSCs) have become a focus of major studies in the last two decades. At present, DSSC is generally either sensitized with inorganic dyes, metal-free organic dyes, or natural dyes. These dyes have emerged as potential alternatives to costly and scarce Ru-based dyes because of being economical, simple attainability, ease of preparation, and environmental friendliness. The majority of alternatives to $\mathrm{Ru}$-based dyes have so far proved to be inferior to $\mathrm{Ru}$-based dyes due to their fragility, narrow absorption bands, and unfavorable dye aggregation. The present review focuses on recent research about sensitizers comprising inorganic dyes, metal-free organic dyes, and natural dyes for DSSCs. Following the introduction, Section 2 describes the DSSC operation, including the essential operational principles and basic components of a DSSC. Section 3 introduces various photosensitizers used in DSSC, and Section 4 states the conclusion and outlook on the field of DSSC research. It also describes and summarizes related sensitizers and their efficiency.
\end{abstract}

Keywords: dye-sensitized solar cells; photovoltaics; sensitizers; solar energy.

(C) 2021 by the authors. This article is an open-access article distributed under the terms and conditions of the Creative Commons Attribution (CC BY) license (https://creativecommons.org/licenses/by/4.0/).

\section{Introduction}

Energy exists in many forms, and it must be transformed from the origin to get its benefit [1]. In general, energy can be retrieved from non-renewable or/and renewable sources. For centuries, non-renewable energy such as fossil fuels and natural gas has been part of our main energy sources. However, we cannot forever depend on these sources because they will inevitably be depleted sooner or later. Activities related to retrieving non-renewable energy sources such as coal mining endanger wildlife, and enormous greenhouse gas emissions from fossil fuels cause global warming [2]. Renewable energy (RE) technologies such as biomass waste, wind, geothermal, hydropower, biofuel, and solar are crucial alternatives to fossil fuels, promoting clean energy without compromising the availability to the next generation [3]. According to the International Renewable Energy Agency (IRENA), the total renewable energy in the world in 2020 is $2,799,094$. Compared to 2019 , which is $2,538,44$, this report indicates a positive growth in the use of RE, showing an increment of about 200,000 in a year 
[4]. Solar energy is chosen above other REs due to the abundance of sunlight, low cost, safety, and cleanliness. Dependency on solar energy was recorded since 8000 B.C, which is mostly used in agriculture [5] and making household products such as clay plates and mugs [6]. Presently, solar energy is acknowledged as the premier sustainable energy source despite its disadvantages $[7,8]$. Solar energy can be harvested using photovoltaic(PV) cells or solar cells, efficiently converting sunlight into electrical energy [9-11]. The mechanism of solar cells can be summarized into four steps: electron-hole pair generation by absorption of light in semiconductors, separation of electron-hole pairs by built-in potential, electron-hole recombination, and collection of charge carriers by the metal electrodes [12].

Silicon is the commonly chosen PV material due to its abundance on Earth [13]. The silicon-based solar cells were introduced in 1954, called high efficiency and cheaper technologies [14]. Photovoltaic cells are categorized into three generations, in which the earliest generation PV cells consisted of monocrystalline and polycrystalline silicon while the following generation PV cells are made of silicon of non-crystalline form, cadmium telluride, and copper gallium indium diselenide. The copper indium selenide (CIS)-based PV cells have also been introduced to increase the efficiency. These PV cells are very stable, have long operational lifetimes, and have achieved over $19 \%$ conversion efficiency [15]. The third generation PV cells consist of DSSCs, quantum dots (QDs), and organic solar cells [16]. The organic-inorganic hybrid perovskite solar cells (PSCs) are fourth-generation PV cells [17]. The DSSC was invented by Professor M. Gratzel in 1991 [18] and became favorable over other PVs due to its low fabrication cost $[9,16,19]$, easy manufacturing process, ability to be processed at ambient temperatures, variety of colors, eco-friendliness [16], high molar absorption coefficient, high performance in indoor conditions under artificial light, and compatibility in roll-to-roll production [16,19]. In this review, the discussion starts with a brief description of DSSC operation. Then, we introduce the types of photosensitizers, and finally, the progress and future challenges are discussed.

\section{DSSC Operation}

The essential operational principles of DSSC solar cells vary from those of ordinary semiconductor solar cells. Light absorption and charge carrier transport activities are not distinctive in semiconductor solar cells. On the other hand, these two activities are separated in a DSSC, in which the charge separation is accomplished by photo-induced injection into the conduction band, and then the generated carriers are delivered to the charge collector [20].

A DSSC consists of a photoanode which is a transparent conducting oxide (TCO) layer on a glass substrate [21], photosensitizers, a counter electrode, and electrolyte, as shown in Figure 1 [20]. The most common TCOs that are used in DSSCs are tin-doped indium oxide (ITO) and fluorine-doped tin oxide (FTO). The TCO layers must have suitable attributes such as low resistivity, high clarity, and smooth surface to achieve high DSSC performance [22]. On the other hand, the photosensitizers or dyes are the main components in DSSCs that have important roles in harvesting the maximum amount of incident light and converting it to electricity [23], whereby the electrolyte promotes charge transfer between photoanode and counter electrode [24]. While the triiodide $\left(\mathrm{I}_{3}^{-}\right)$serves as a mediator to regenerate the sensitizers [25]. The general working principle of DSSC is based on four prominent steps, which start from light absorption followed by electron injection, then transportation of charge carrier, and finally, collection of current. When photons from the light spectrum are struck on 
the photoanode, the dye in its ground state absorbs photons from sunlight, and the electrons are excited from the highest occupied molecular orbital (HOMO) to the lowest unoccupied molecular orbital (LUMO). The excited electrons in the dye are injected into the conduction band of the TCO and then flow via the external circuit from the TCO layer to the counter electrode. The dye is then regenerated due to accepting electrons from the redox mediator, and the redox mediators are regenerated by accepting electrons from the counter electrode. Lastly, the whole process is repeated continuously to complete the circuit [23].

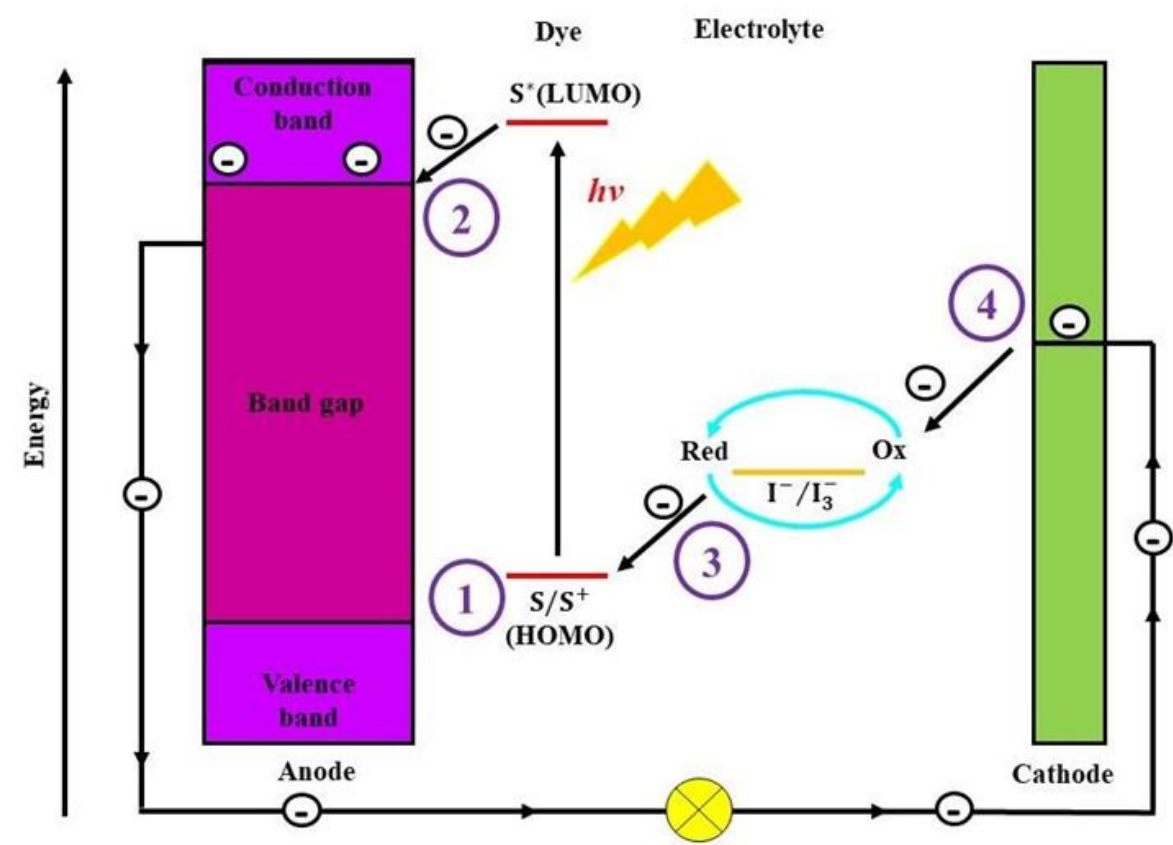

Figure 1. Basic working principle of a DSSC.

\section{Photosensitizers Used in DSSCs}

To ensure a longer light-harvesting time, the sensitizers should be able to harvest light in a wide absorption range, ideally from the visible $(\sim 400 \mathrm{~nm})$ to the near-infrared region $(\sim 800$ $\mathrm{nm})[9,16,18]$. A sensitizer or dye also acts as a molecular electron pump in the DSSC by pumping an electron into TCO's conduction band and can be regenerated promptly by the redox couple [26,27]. For efficient charge injection into the semiconductor, sensitizers must have chemical stability at the relevant highest occupied molecular orbital (HOMO) and lowest unoccupied molecular orbital (LUMO) levels [19,20]. Prompt dye regeneration from the electrolyte will decrease the energy loss because the charge-recombination process is the main competitor to the dye regeneration process [28]. Charge recombination, which occurs at pinholes, will limit the cells' performance. In short, the sensitizers must be stable both photochemically and electrochemically for efficient performance [23,29-36]. Massive efforts have been undertaken to create various sensitizers, which may roughly be classified as follows: Natural dyes; Metal-free organic dyes; Inorganic dyes.

\subsection{Natural dyes.}

Natural dyes are pigments extracted from and used in DSSCs as an alternative to replacing the limited and expensive Ruthenium(II) complexes. Because of their environmental friendliness, the low price [37], high absorption coefficients in the visible range, ease of production, and relative abundance, these natural dyes have great features as sensitizers in 
DSSCs [38,39]. Furthermore, compared to synthetic dyes, the extraction procedure of natural color pigments such as chlorophyll, carotenoids, betalains, and flavonoids is relatively easy [40].

\subsubsection{Chlorophyll.}

Chlorophylls are pigments that give the green color in plants and algae. There are six different types of chlorophyll pigments, and the major ones are chlorophyll $\alpha$ (Chl- $\alpha)$ with maximum absorption at $670 \mathrm{~nm}$ and chlorophyll $\beta(\mathrm{Chl}-\beta)$ at $470 \mathrm{~nm}$. A porphyrin ring is the fundamental molecular shape of the chlorophyll [41] that acts as the center to gather the sunlight, transport electrons and convert solar energy to chemical energy [42]. Because of their capacity to absorb light spectrum in visible wavelengths, chlorophylls and their derivatives are widely used as sensitizers in DSSCs [41-43]. However, due to the steric hindrance that occurs because of its long chain length, chlorophyll alone is not favorable to be used as sensitizers because this disadvantage affects the electron transport rate and reduces the potential of the electrons to be injected into the semiconductor's conduction band. Moreover, the absence of right anchoring groups worsens these conditions [41,43]. It was recorded that the chlorophyll extracted from bryophyte Hyophila exhibited an efficiency of $2.00 \%$ when used as a sensitizer in DSSC [44], which was much lower compared to N719.

\subsubsection{Carotenoids.}

Carotenoids are a vast family of isoprenoids with about 600 members characterized by a C40 hydrocarbon backbone [45]. Carotenoids are naturally occurring brilliant color pigments in all photosynthetic organisms such as plants, cyanobacteria (multicellular organisms), and algae (unicellular organisms) [46] which can absorb wavelengths of light ranging from $380 \mathrm{~nm}$ to $550 \mathrm{~nm}$ and also responsible for the quenching of light and protect cells from damages caused by light and superoxide radicals [47-49]. These pigments excel as energy collectors and photosensitizers suitable for being engaged as sensitizers in DSSCs [50]. However, long alkyl chains also cause steric hindrance and make assembling the semiconductor film problematic because of the lack of efficient functional groups to bind with the hydroxylic group of the $\mathrm{TiO}_{2}$ [51]. Kumara et al. reported that the highest efficiency of the carotenoids-based sensitizer is $2.6 \%$, and conversion efficiency of $4.2 \%$ is achieved when carotenoids and chlorophyll derivatives are combined [52].

\subsubsection{Betalains.}

Betalains are a small category of water-soluble and nitrogen-containing vacuolar pigments found in the vacuoles of cells of Caryophyllales plants, consisting of amino compounds and immonium conjugates of betalamic acid with cyclo-Dopa (cyclo3,4dihydroxyphenylalanine). These pigments can be classified into betaxanthins and betacyanins. The yellow-orange color of betaxanthins results from the different amino acids or amine side chains whilst different substitution patterns resulting red and violet tonalities in betacyanins. Both pigments retain a higher extinction coefficient in the visible range between $476 \mathrm{~nm}$ and $600 \mathrm{~nm}$, while their redox properties are determined by the $\mathrm{pH}$ of the solution [43]. The betalain-based sensitizers successfully bind to the $\mathrm{TiO}_{2}$ due to the presence of carboxylic functional groups, and the efficiencies are recorded around $0.5 \%$ up to $2.0 \%$. The highest power conversion efficiency (PCE) recorded for betanidin extract used in a DSSC is 3.04\% (Table 1) 
with a wide light spectrum absorption from $300 \mathrm{~nm}$ to $700 \mathrm{~nm}$ and exhibited higher stability during solar irradiation [53]. Thus, betalains are indeed some of the good alternatives to synthetic colorants for DSSCs. However, due to their short electronic singlet state $\left(\mathrm{S}_{1}\right)$ lifetime [41], the efficiencies and open-circuit voltage $\left(\mathrm{V}_{\mathrm{OC}}\right)$ can be low, and the insufficient electron injection quantum yield also lead to poor performance of betalains as sensitizers in DSSC. This electron injection is affected by a short $S_{1}$ lifetime responsible for a rapid internal conversion process [54].

\subsubsection{Flavonoids.}

Flavonoids are found in many parts of plants, such as roots, bark, stems, flowers, and in addition to others with variable phenolic structures [55]. Flavonoids are very important pigments that contribute to the coloration of many fruits and flowers, and they can be categorized into aurones, chalones, anthocyanins, flavones, and flavonols. Flavonoids can be distinguished from one another by the $\gamma$ ring, which connects the two benzene rings. In addition, the flavonoids have a basic $\mathrm{C}_{6}-\mathrm{C}_{3}-\mathrm{C}_{6}$ structure which defines the colors of different flavonoids by the degree of phenyl ring oxidation [56]. Flavonoids are currently regarded as essential components due to their anti-mutagenic, anti-oxidative, anti-carcinogenic, and antiinflammatory properties [43], as well as being unique ultraviolet (UV) filters [55]. In contrast, despite their similarities, several flavonoids are known to receive visible light spectra $[41,42]$. Anthocyanins are the most important pigments in the flavonoids family for the DSSCs applications due to their ability to transfer electrons orderly and harvest light in the visible region of the light spectrum. These pigments instantaneously form bonds with semiconductors via chelation mechanisms using carbonyl and hydroxyl functional groups [52]. There are 17 different structures identified for anthocyanins, and they are classified according to the number of sugar molecules [42]. Anthocyanins can be extracted from water, alcohols, or mixtures by adding a little acid in order to prevent any material eradication [57].

In Table 1, modified chlorophyll pigments show the highest efficiencies, whilst the anthocyanin dyes show efficiencies less than $1.0 \%$ in DSSCs. Still, the betalain dyes show a DSSC efficiency of more than $1.0 \%$ compared to chlorophyll pigments. The restriction of light absorption ability and poor bonding of natural dyes cause negative efficiency of these natural dyes. Numerous techniques, such as combining two or more natural dye pigments, can improve the light absorption capability. For instance, the bonding between molecules and semiconductors is improved when anthocyanins combine chemically with glycosides or/and with acyl groups. Adsorption of natural dyes successively increases dye loading and pre-dye adsorption. This subsequently boosts conversion efficiency and enhances the incident photo conversion efficiency (IPCE) of natural DSSCs [43].

Table 1. Natural dyes and structural classes used in DSSCs.

\begin{tabular}{|c|c|c|c|c|c|}
\hline Plant source/ Dye & Structure/structural class & $\mathrm{JSC}_{\mathrm{SC}}\left(\mathrm{mA} / \mathrm{cm}^{2}\right)$ & $\operatorname{Voc}_{\text {oC }}(\mathbf{V})$ & $\eta(\%)$ & References \\
\hline Blueberry & Anthocyanins & 4.1 & 0.30 & 0.69 & {$[58]$} \\
\hline Amaranthus caudatus flower & Chlorophyll & 1.82 & 0.55 & 0.61 & [59] \\
\hline Cordyline fruticosa leaves & Chlorophyll & 1.30 & 0.61 & 0.50 & {$[60]$} \\
\hline Papaya leaves & Chlorophyll & 0.36 & 0.32 & 0.07 & [61] \\
\hline Azadirachta indica leaves & Chlorophyll & 0.43 & 0.40 & 0.72 & [62] \\
\hline Basil leaves & Chlorophyll & 1.39 & 0.58 & 0.40 & [63] \\
\hline Ziziphus jujube leaves & Chlorophyll & 3.18 & 0.65 & 1.07 & [63] \\
\hline Mint flower & Chlorophyll & 0.45 & 0.54 & 0.09 & [64] \\
\hline Lemon leaves & Chlorophyll & 1.08 & 0.59 & 0.03 & [65] \\
\hline Morula leaves & Chlorophyll & 0.05 & 0.47 & 0.01 & [65] \\
\hline
\end{tabular}




\begin{tabular}{l|c|c|c|c|c}
\hline Plant source/ Dye & Structure/structural class & $\mathbf{J S C}\left(\mathbf{m A} / \mathbf{c m}^{\mathbf{2}}\right)$ & Voc $(\mathbf{V})$ & $\eta(\%)$ & References \\
\hline Fig leaves & Chlorophyll & 2.09 & 0.59 & 0.64 & {$[63]$} \\
\hline Berry leaves & Chlorophyll & 3.57 & 0.59 & 0.93 & {$[63]$} \\
\hline Banana leaves & Chlorophyll & 1.77 & 0.59 & 0.52 & {$[63]$} \\
\hline Peach leaves & Chlorophyll & 2.55 & 0.61 & 0.65 & {$[63]$} \\
\hline Black tea leaves & Chlorophyll & 0.39 & 0.55 & 0.08 & {$[64]$} \\
\hline Hierochloe odorata grass & Chlorophyll & 2.19 & 0.59 & 0.46 & {$[66]$} \\
\hline Torulinium aegyptium grass & Chlorophyll & 1.00 & 0.65 & 0.32 & {$[66]$} \\
\hline Flowers, fruits & Carotenoids & - & - & 2.60 & {$[52]$} \\
\hline SPA dyes & Betalains & 9.08 & 0.632 & 3.04 & {$[53]$} \\
\hline Tangerine peel & Flavone & 0.74 & 0.592 & 0.28 & {$[67]$}
\end{tabular}

\subsection{Metal-free organic dyes.}

Organic dyes have piqued the interest of researchers interested in using them as sensitizers in DSSCs because of their distinct characteristics such as affordable prices, broad absorption of the solar emission spectrum, higher molar extinction coefficients, and most importantly, ease of extraction and purification procedure [68]. Metal-free organic dyes are usually constructed by an electron donor (D), $\pi$-conjugation bridge, and an electron acceptor (A). This design is called a D- $\pi$-A system, 'push-pull' structure or 'DpA'. Donor groups are usually electron-rich moieties like (difluorenyl) triphenylamine, aminocoumarin, indoline, phenylamine, carbazoles, and triarylamines. Thiophene, benzothiadiazole, and benzene [27,69] are known to be excellent choices as $\pi$-conjugated bridges because these compounds can widen the light absorption range up to the near-infrared radiation. The power conversion efficiency of DSSCs can be increased by increasing the number of thiophene $\pi$-bridging units [70]. Various acceptors such as benzotriazole, phthalimide, benzothiazole, thienopyrazine, and quinoxaline have become prominent building blocks to functionalize conjugated organic sensitizers with a low bandgap and tunable LUMO level [71]. In addition, these acceptors also will act as an anchor to the semiconductor layer [72]. Trialkoxysilyl groups, carboxylic acids, and their derivatives are among the best anchoring groups for bidentate bridging with metal oxide, compared to the less stable monodentate anchoring [71]. However, organic dyes have low conversion efficiencies compared to metal complexes-based dyes. The development of dye aggregates on the surface of $\mathrm{TiO}_{2}$ nanoparticles results in the oppression of the excited state of the sensitizer molecules, which can limit the effectiveness of the DSSC, but there are a few metal-free organic dyes like triphenylamine, coumarin, alizarin, carbazole, and cyanine-based sensitizers which successfully achieved efficiency of up to 5-9\%. For instance, alizarin is a red substance capable of absorbing visible light spanning from 400 to $600 \mathrm{~nm}$ and allows fast injection of electrons into the semiconductor conduction band via indirect processes [72]. Saini et al. reported [73] that DSSCs with alizarin-based sensitizers had recorded efficiencies of about $0.635 \%, 0.788 \%, 0.383 \%$ and $0.915 \%$ when redox couple electrolytes such as potassium iodide $(\mathrm{KI}), \quad$ tetraethylquaternaryammonium iodide $\left[\left(\mathrm{CH}_{3} \mathrm{CH}_{2}\right)_{4} \mathrm{NI}\right]$, tetramethylquaternaryammonium iodide $\left[\left(\mathrm{CH}_{3}\right)_{4} \mathrm{NI}\right]$ and tetrapropylquaternaryammonium iodide $\left[\left(\mathrm{CH}_{3} \mathrm{CH}_{2} \mathrm{CH}_{2}\right)_{4} \mathrm{NI}\right]$ were employed . Besides that, the DSSC with an alkoxysilyl-anchor dye (ADEKA-1) and a carboxy-anchor organic dye of 3-\{6\{4-[bis(2',4'-dibutyloxybiphenyl4-yl)amino-]phenyl \}-4,4-dihexyl-cyclopenta-[2,1-b:3,4b']dithiophene-2-yl \}-2-cyanoacrylic acid (LEG4) collusion have been tested and showed outstanding efficiencies, up to $14.30 \%$ [74]. Moreover, the LEG4 dye can achieve high efficiency of about 5.8\% at the wavelengths from $320 \mathrm{~nm}$ to $350 \mathrm{~nm}$ and $520 \mathrm{~nm}$ to $580 \mathrm{~nm}$ [75]. Besides the D- $\pi$-A system, other designs like D-A-A and D-D - A-type organic dye structures have been introduced to enhance the efficiency of DSSCs by introducing a subordinate acceptor or donor similar to 2,3- 
diphenylquinoxaline/3,6-ditert-butylcarbazole to inhibit dye aggregation, promote electron migration and improve photostability [69]. The auxiliary electron-drawing group (A) might be thought of as an 'electron trap' is which can enhance the photo and thermal steadiness, increase the open-circuit voltage and shift the absorption range to near infra-red [76].

\subsection{Inorganic dyes.}

\subsubsection{Ruthenium sensitizers.}

Ruthenium(II) complexes with polypyridyl ligands have been used as photosensitizers for over 30 years because of their ability to form strong bonds with the donor nitrogen atoms of organic ligands in addition to their tunable photophysical, photochemical, and electrochemical properties [77]. Ru metal was recognized as a complex-forming metal due to its atom's octahedral coordination condition, which exhibits stable and accessible oxidation states ranging from I to IV, allowing it to coordinate with many ligands [78,79]. The Ru trinuclear complex with enhanced absorption properties was discovered by O'Regan and Grätzel in 1991 as the first efficient sensitizer in DSSC [18]. The Ru-based DSSC recorded excellent conversion efficiency of incident photons to the electrical current of over $80 \%$. Moreover, on average, around 10\% light-to-electric energy conversion is recorded under diffuse daylight and simulated solar light [18]. In 1993, a series of Ru(II) complexes with general formula cis- $\mathrm{X}_{2}$ bis(2,2'-bipyridyl-4,4'-dicarboxylate)- $\mathrm{Ru}(\mathrm{II})$ where $\mathrm{X}=\mathrm{Cl}, \mathrm{Br}, \mathrm{I}, \mathrm{CN}$, and SCN were introduced, and the optical and electrochemical properties were studied intensively by Nazeeruddin et al. [80]. The Ru(II) complex containing two groups of isocyanate ligands, N3 showed an extraordinary photovoltaics attribute. The dye adsorption spectrum was red-shifted up to $800 \mathrm{~nm}$, and the DSSC's efficiency was extended up to $10 \%$ with a high Jsc $\left(18.2 \mathrm{~mA} / \mathrm{cm}^{2}\right)$. Polypyridine derivates were selected as ligands for enhancing certain electrochemical and photophysical attributes of sensitizers by adding substituents into the heteroaromatic ring. For example, the $\mathrm{Ru}(4,4$ '-dicarboxylic acid-2,2'-bipyridine)(4,4'-Di(3methoxystyryl)-2,2'bipyridine)(NCS) 2 (Z910) dyes consist of bipyridyl ligand and methoxystyryl group, and the overall efficiency achieved was $10.2 \%$ for the DSSC constructed by engaging this dye [81]. N719 or di-tetrabutylammonium cis-bis(isothiocyanato)bis(2,2'bipyridyl-4,4'dicarboxylato)ruthenium(II) is the best $\mathrm{Ru}(\mathrm{II})$-based photosensitizer for DSSC with a high overall efficiency of $11.2 \%$ as shown in Table 2 [82]. The N3 and N719 had been set as reference dyes and used as the benchmark to plan new Ru-based photosensitizers by manipulation of the ancillary ligands [19]. Not long after that, Nazeeruddin MK et al. discovered the black dye (N749) with absorption spectra ranging from visible to near-infrared, up to $920 \mathrm{~nm}$. It was recorded that the DSSC with N749 dyes achieved $10.4 \%$ overall efficiency with $\mathrm{J}_{\mathrm{sc}}$ of $20.53 \mathrm{~mA} / \mathrm{cm}^{2}$ [83]. On the other hand, Thiocyanate ligands are widely used in applications due to their excellent electron-donating properties. However, this ligand is less stable in the complexes. For example, dye degradation of N719 happens when the dye is chemisorbed on the $\mathrm{TiO}_{2}$ particles [84]. The presence of co-adsorbent (hexadecylmalonic acid) on the $\mathrm{TiO}_{2}$ can increase the dye's stability because the constructed hydrophobic layer blocks the desorption process of the dye by residual water while forming an impervious layer between the semiconductor and the electrolyte. For instance, cis-bis(isothiocyanato)(2,2'-bipyridyl4,4'-dicarboxylato)(4,4'-di-nonyl-2,2'bipyridyl) ruthenium (II) (Z907) dyes have achieved $7.8 \%$ efficiency in a DSSC and have long-term stability at $55^{\circ} \mathrm{C}$ contributed by the presence of the co-adsorbent [85]. Another dye, $\mathrm{NaRu}$ (4-carboxylic acid-4'-carboxylate)(4,4'- 
bis[(triethylene glycol methyl ether)methyl ether]-2,2'-bipyridine)-(NCS) 2 (K51), which is composed of a triethylene oxide methyl ether group, achieved $8.1 \%$ efficiency by adjusting the concentration of lithium ions in the electrolyte [86]. The lithium ions will intercalate or aggressively adsorbs to the surface of $\mathrm{TiO}_{2}$. The surface adsorption produces a positive shift in the $\mathrm{TiO}_{2}$ conduction band, resulting in a significant decrease in the cell's open-circuit voltage. On the other hand, the efficiency of $\mathrm{Ru}$ (4,4-dicarboxylic acid-2,2'-bipyridine)(4,4'-bis(2-(4(1,4,7,10-tetraoxyundecyl)phenyl)ethenyl)-2,2'-bipyridine)(NCS) 2 (K60) dyes is increased to $8.4 \%$ by lengthening the conjugation of the peripheral ligands, and their durability is longer when exposed to $60^{\circ} \mathrm{C}$ of direct sunlight [87]. Even though thiophene groups are less stable in the complexes, Chen et al. did introduce a ruthenium dye with an alkyl bithiophene group in CYCB 1 dyes, which had thiophene groups in its ancillary ligands. Surprisingly, the efficiency recorded was at par with the references dyes [88]. CYC-B11 dye is the innovation from CYCB1 dyes by substituting the alkyl chain with an electron-rich thioalkyl group in order to obtain much higher efficiency [89]. In addition, cis-Bis(isothiocyanato)(2,2'-bipyridyl4,4'dicarboxylato)(4,4'-bis(5-hexylthiophen-2-yl)-2,2'-bipyridyl)ruthenium(II) (C101) [90] and cis-Bis(isothiocyanato)(2,2'-bipyridyl-4,4'-dicarboxylato)(4,4'-bis(5(hexylthio)thiophen-2yl)-2,2'-bipyridyl)ruthenium(II) (C106) dyes [91] are other examples of $\mathrm{Ru}$-based sensitizers in which the bipyridine ligand is functionalized by a single thiophene ring. The DSSCs constructed with both dyes recorded $11.7 \%$ and $10.57 \%$ overall efficiencies. The insertion of electron-donating antennas in the auxiliary ligands, on the other hand, resulted in an efficiency of 10.78 percent for the heteroleptic polypyridyl ruthenium complex (RC-43) dyes. In RC-43, a stronger electron-donating antenna-methoxy-triphenylamine (MeO-TPA)-is connected to the bipyridine ligand, while the spacer is used between the MeO-TPA and bipyridine units is ethylene-dioxythiophene (EDOT) to increase the ancillary bipyridine ligand's electron-donating capacity and conjugation length [82]. The derivation diimine ligands of 4,5diazafluorene (C2, C3) and the $\mathrm{Ru}(\mathrm{II})$ complexes also show photovoltaic properties. The $\mathrm{C} 2$ ligand is bound to a catechol anchoring group, while $\mathrm{C} 3$ ligand is bound with boronic acid. Occasionally, carboxylic acids are used as an anchoring group, but the low pKa values weaken the binding between sensitizers and $\mathrm{TiO}_{2}$, which causes sensitizers to disengage from the $\mathrm{TiO}_{2}$ surface in the existence of water. Alternative anchoring groups such as catechol and boronic acid are introduced to overcome these limitations. The boronic acid has two monodentate or four bridging bidentate anchoring modes on the $\mathrm{TiO}_{2}$, which makes it favorable as a substitute to carboxylic acid anchors [92]. Whereas the five-membered ring constructed between $\mathrm{Ti}^{4+}$ and the catechol moiety influenced the superiority of the binding between the complexes and the anchoring groups to the $\mathrm{TiO}_{2}$ surface. Even though prior studies of catechol anchoring groups do not go over $2 \% \mathrm{PCE}$, the $\left[\mathrm{Ru}(\mathrm{C} 2)_{2}(\mathrm{NCS})_{2}\right]\left(\mathrm{PF}_{6}\right)_{2}$ sensitized cell recorded the best PCE at $2.83 \%$ when chenodeoxycholic acid (CDCA) was added to it, which enhanced its performance by stopping dye aggregation and obstructing charge recombination [92].

Table 2. List of Ru-based sensitizer used in DSSCs.

\begin{tabular}{l|c|c|c|c|c} 
Dyes & $\mathbf{J}_{\mathbf{s c}}\left(\mathbf{m A} / \mathbf{c m}^{\mathbf{2}}\right)$ & $\mathbf{V}_{\mathbf{o c}}(\mathbf{V})$ & $\mathbf{F F}$ & $\eta \mathbf{( \% )}$ & References \\
\hline $\mathbf{N 3}$ & 18.2 & 0.72 & 0.73 & 10.00 & {$[80]$} \\
\hline $\mathbf{N 7 4 9}$ & 20.53 & 0.72 & 0.704 & 10.40 & {$[83]$} \\
\hline $\mathbf{Z 9 0 7}$ & 14.2 & 0.764 & 0.676 & 7.80 & {$[85]$} \\
\hline $\mathbf{Z 9 1 0}$ & 17.2 & 0.777 & 0.764 & 10.20 & {$[81]$} \\
\hline K51 & 16.6 & 0.738 & 0.679 & 8.10 & {$[86]$} \\
\hline CYC-B1 & 23.92 & 0.65 & 0.54 & 8.54 & {$[88]$} \\
\hline $\begin{array}{l}\text { K60 } \\
\text { https://biointerfaceresearch.com/ }\end{array}$ & 16.7 & 0.715 & 8.44 & {$[87]$} \\
\hline
\end{tabular}




\begin{tabular}{l|c|c|c|c|c}
\hline Dyes & $\mathbf{J}_{\text {sc }}\left(\mathbf{m A} / \mathbf{c m}^{\mathbf{2}}\right)$ & $\mathbf{V}_{\text {oc }}(\mathbf{V})$ & $\mathbf{F F}$ & $\eta \mathbf{( \% )}$ & References \\
\hline N719 & 17.73 & 0.846 & 0.75 & 11.20 & {$[82]$} \\
\hline CYC-B11 & 20.05 & 0.743 & 0.77 & 11.50 & {$[89]$} \\
\hline C106 & 18.28 & 0.749 & 0.772 & 10.57 & {$[91]$} \\
\hline C101 & 10.5 & 0.747 & 0.76 & 11.70 & {$[90]$} \\
\hline RC43 & 20.21 & 0.725 & 0.73 & 10.78 & {$[93]$}
\end{tabular}

3.3.2. Copper sensitizers.

Metals such as copper, manganese, iron, nickel, and zinc are used to fabricate inorganic dyes in the quest to discover earth-abundant alternatives to ruthenium. The capability to recycle copper from thrown electronics and other scrap metals helps the maximum utilization of copper. In 2015, nearly one-third of the used copper originated from recycled copper because copper does not deteriorate or lose its chemical or physical attributes in the recycling process [94]. $\mathrm{Cu}$ forms complexes in the oxidation states +1 and +2 ; nevertheless, the shape of the complexes is distinctive. Copper(I) complexes desire a tetrahedral coordination domain which permits more structural distortions than other complexes with higher coordination numbers. The earliest copper coordination compounds used in DSSCs were homoleptic $\mathrm{Cu}(\mathrm{I})$ complexes, although the efficiencies achieved were around $0.1 \%$ to $3.0 \%$. It was recorded that the copper complex that coordinated with two 6,6'-dimethyl-2,2'-bipyridine-4,4'-dibenzoic acids showed $33 \%$ relative efficiency with respect to $100 \%$ of N179 as the reference dye. Homoleptic dyes are less efficient as sensitizers than heteroleptic dyes because they cannot merge efficiently with anchoring and ancillary domains [95]. A completely equipped DSSC was constructed by the Constable and his co-workers with $\left[\mathrm{Co}(\mathrm{bpy})_{3}\right]^{2+/ 3+}$ as the redox couple, and the heteroleptic $\mathrm{Cu}(\mathrm{I})$ complexes dye consists of anchoring ligand and ancillary ligand which were $\left(\left(6,6^{\prime}-\right.\right.$ dimethyl-[2,2'-bipyridine]-4,4'-diyl)bis(4,1-phenylene)bis(phosphonic acid)) and 2(diphenylaminophenyl)-1H-phenanthrol[9,10-d]imidazole derivative, respectively. This DSSC achieved $1.73 \%$ efficiency and $25 \%$ relative efficiency compared with reference $\mathrm{I}^{-} / \mathrm{I}_{3}{ }^{-}$ electrolyte [96]. In 2014, Odobel and co-workers reported a fully masked heteroleptic copperbased DSSC with $4.66 \%$ photoconversion effectiveness concerning $\eta \sim 7.5 \%$ in $N 719$, the reference dye [95].

The engagement of porphyrins as sensitizers in DSSCs has lately increased. It was reported that the energy conversion efficiency of a DSSC sensitized with $\mathrm{Cu}$ (II)-porphyrin complexes easily reached up 2.6\% [97-99]. The absorption of porphyrins is influenced by the substituents linked to the macrocycle, the identity of the complexed metal ion, and the position of those substituents. For instance, the incompleted orbital of copper(II) ion was contributed to the Soret band of copper(II) complex of 5,10,15,20-tetrakis-(3,4-dibenzyloxyphenyl)porphyrin (CuTDBOPP). This shift happens due to metal-to-ring charge transfer, which raises the energy of the $\pi$ to $\pi^{*}$ transition in the porphyrin ligand. At the same time, the maximum wavelength was seen to be altered when the metal was inserted into the porphyrin. This CuTDBOPP dye is a symmetrical porphyrin that is easy to synthesize with changeable substituents. CuTDBOPP dye is used to make statistically significant comparisons between the efficiency of solar cells made with various porphyrins. The open current-voltage $\left(\mathrm{V}_{\mathrm{oc}}\right)$ of CuTDBOPP cell is almost $52 \%[100]$.

\subsubsection{Zinc sensitizers.}

Porphyrin possesses two types of absorption bands in the visible region which are Soret and Q-bands, which are located in the red and blue regions [101-103]. The position of these 
bands can be altered by changing the ligand of the complexes and subsequently increasing the number of photons that are absorbed by the complexes. Thus, the efficiency of DSSC can be increased tremendously. Porphyrin compounds have high molar extinction coefficients, are cheaper, are facile to synthesize, and are environmentally friendly. A DSSC sensitized by zinc porphyrin complex shows an open circuit potential $\left(\mathrm{V}_{\mathrm{oc}}\right)$ of 0.65 and a short current density $\left(\mathrm{J}_{\mathrm{sc}}\right)$ of 11.60 with a PCE of about $5.53 \%$. The high effectiveness of the $\mathrm{Zn}$ porphyrin complex sensitized cell can be associated with great electron injection outcome and low charge recombination rate due to large attachment groups that refrain the accumulation of dye on the $\mathrm{TiO}_{2}$ surface. The accumulation of dye molecules on the $\mathrm{TiO}_{2}$ electrode surface increases intermolecular charge transfer between dye molecules while suppressing charge transfer from dye molecules to the $\mathrm{TiO}_{2}$ electrode surface. In addition, the value of $\mathbf{J}_{\mathrm{sc}}$ can be affected by the molar extinction coefficient of the dye molecule. A high molar extinction coefficient, in general, has a robust light-harvesting potential and gives a great $\mathbf{J}_{\mathrm{sc}}$. Porphyrin dye's incident photon-to-current conversion efficiency (IPCE) exhibits a maximum plateau around $550 \sim 700$ $\mathrm{nm}$. The IPCE value of a DSSC depends on the effectiveness of electron injection into the conduction band of metal oxide [104]. Employing high $\pi$-delocalized substituents will help to boost the light-harvesting features and photovoltaic potentials of the DSSCs.

Insuasty and co-workers synthesized new porphyrin dyes consisting of diphenylamineZn(II)-porphyrin with vinylfluorene as the $\pi$-bridge, and cyanoacrylic acid or dicyanorhodanine as the anchoring groups [105]. Among these dyes, the dyes with a cyanoacrylic acid acceptor group exhibited the highest photocurrent densities with $4.13 \%$ PCE. This is because cyanoacrylic acid anchoring group is prone to facilitating fast electron injection into the semiconductor and arranging the dyes perpendicularly to the $\mathrm{TiO}_{2}$ surface. The perpendicular orientation hinders immediate inner-path recombination between the semiconducting electrode and the dye cation after the electron injection.

\subsubsection{Iron sensitizers.}

Iron metal is one of the environmentally friendly d-block elements which exhibit intense MLCT absorption. Making iron complexes usable in DSSCs, on the other hand, is extremely difficult due to the rapid deactivation of MLCT states into metal-centered (MC) states and the impedance of electron injection into the sensitized semiconductor [106-108].

In Fe(II) polypyridyl complexes, for example, the MLCT states lie at higher energy than MC states, as shown in Figure 2. This eventually causes the photon energy to be available only in a very short period of time, and the functional photochemical process becomes shorter than the intramolecular relaxation rates. The effectiveness of $\mathrm{Fe}(\mathrm{II})$ sensitizers can be enhanced by making the interfacial electron transfer (IET) quicker than the intersystem crossing (ISC) procedure by elevating the rate of IET via constructional adjustment in the ligands of sensitizing dyes. In addition, the application of a hydroxamate linker instead of a carboxylic acid linker increases the amount of IET. Thus, Fe(II) polypyridines with hydroxamate are more effective as photosensitizers. Furthermore, engaging strong-field ligands around the iron center helps delay the ISC process if pseudo $t_{2 g}$ and $e_{g}$ orbitals are more separated. By contrast, the addition of electron-acceptor group and ligand with longer $\pi$-conjugation also subsequently lowers the energy of MLCT states [111]. Iron-based sensitizers for DSSCs were first introduced by Ferrere using the Fe(dcbpy)2(CN)2 dye [112]. However, there was no significant progress since then until Wärnmark and co-workers found that the N-heterocyclic carbenes 
(NHC) could increase the MLCT lifetime caused by the destabilization of MC states which was affected by strong $\pi$ donating effects [113-115]. Iron(II) bipyridyl complexes with NHS ${ }^{-}$ axial ligands are characterized by both MLCT and ligand-to-ligand charge transfer (LLCT) in the range of 350-700 nm [84]. It was recorded that the PCE for a DSSC sensitized with homoleptic Iron-NHC complexes achieved $0.13 \%$ and $0.03 \%$ efficiencies. Whilst, the heteroleptic Iron-NHC complexes achieved PCEs of $0.10 \%, 0.11 \%$ and $0.10 \%$ [116].

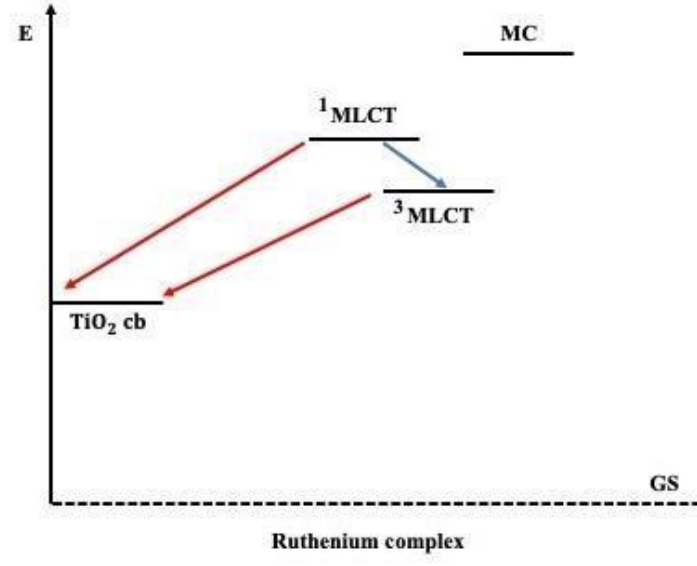

(a)

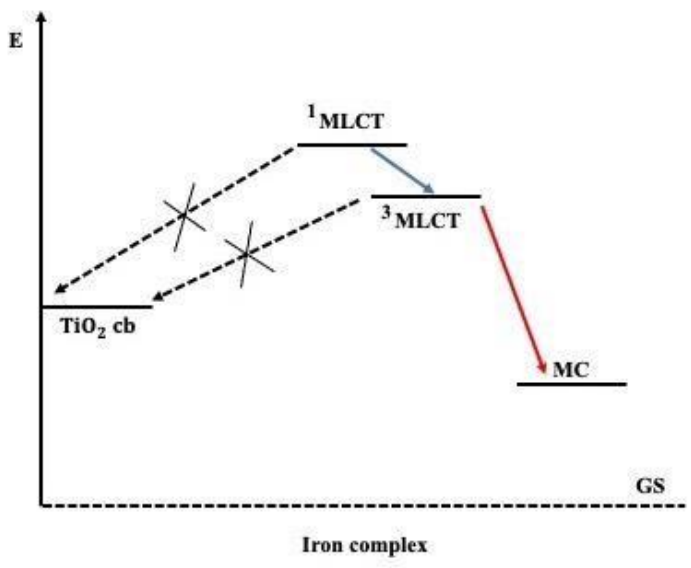

(b)

Figure 2. Energetic diagrams of (a) Ruthenium polypyridine complexes; (b) Iron polypyridine [109,110].

Quercetin is a flavonoid molecule with numerous hydroxyl groups that could easily form complexes with metals like $\mathrm{Au}^{3+}, \mathrm{Os}^{8+}, \mathrm{Fe}^{2+}, \mathrm{Fe}^{3+}, \mathrm{Cu}^{2+}, \mathrm{Zn}^{2+}, \mathrm{Al}^{3+}, \mathrm{Ru}^{3+}$ and so forth. The UV-Vis absorbance spectrum of Fe-quercetin complex dye is strong in the visible region and reaches the near-infrared region. The highest absorption bands of Fe-quercetin appear at $453 \mathrm{~nm}$, with a significant red shift. The color of quercetin solution is yellow; however, it can change to dark brown from yellow in some cases. This color changer affects the UV-Vis absorption of the sensitizers as well as their cell effectiveness. Because of the improved lightharvesting room, the efficiency of the quercetin-iron dye DSSC is 67 percent greater than that of the quercetin-based cell [117].

\subsubsection{Cobalt sensitizers.}

Many other types of inorganic and organic dyes have lately been employed as sensitizers, and the influence of their structures on the PCE has been thoroughly studied $[36,118,119]$. The results demonstrate a close link between PCE, the dye ligand structure, and the maximum absorption wavelength. Even though bipyridine ligand-based copper complexes are proven to be high-efficiency sensitizers owing to fast electron transfer, their efficiency are still under par for commercialization [120].

In 2019, Chenab and co-workers introduced cobalt complex of 2, 3, 4, 5tetra(4pyridyl)thiophen ligand with nitrate anchoring groups as sensitizers for DSSCs. This cobalt complex sensitized DSSC exhibited high light-harvesting efficiency (LHE) with ample absorption wavelength at $498 \mathrm{~nm}$ and $650 \mathrm{~nm}$ with good photovoltaic parameters such as fast $\eta_{\text {reg }}$ and acceptable $\eta_{\text {coll. }}$ Despite high LHE around $\sim 61 \%$, cobalt complex sensitized DSSCs usually suffer from low quantum efficiency of electron injection $\left(\varphi_{\text {ing }}\right)$ caused by low shortcircuit current, which is highly affected by the cobalt complex molecular structure [121]. 


\section{Conclusions and Outlook}

In this paper, we reviewed the versatility of photosensitizers that exist in DSSCs. Recent progress of photosensitizers in DSSC currently focuses on natural dyes, metal-free organic dyes, and inorganic dyes. $\mathrm{Ru}(\mathrm{II})$ is the first element used for DSSC, found by O'Regan and Grätzel in 1991. This precious element has unique characteristics such as octahedral coordination geometry that allows for fabricating various complexes with numerous ligands and excellent redox properties with good stability. The highest recorded efficiency of DSSC Ru-based sensitizer is up to $10 \% \sim 11 \%$. However, due to the scarcity and toxicity of Ru metal, alternative sensitizers such as natural dyes, metal-free organic dyes, and inorganic dyes have been introduced. Although these sensitizers are economical and environmentally friendly, they have lower efficiencies than $\mathrm{Ru}$, hindering commercialization. For instance, the highest efficiency recorded for natural dye sensitizers is only around $3.04 \%$, whereby metal-free organic dyes and inorganic dyes are up 5.56\%.

Nevertheless, organic dyes are facile to be synthesized with less complicated purification steps compared to inorganic dyes. There are various ways to improve the quality of the dye sensitizers for commercial purposes. Based on current studies, hybridizations between two metal-free organic dyes such as alkoxysilyl-anchor dye (ADEKA-1) and a carboxy-anchor organic dye of 3-\{6-\{4-[bis(2',4'-dibutyloxybiphenyl-4-yl)amino]phenyl 4,4-dihexyl-cyclopenta-[2,1-b:3,4-b']dithiophene-2-yl \}-2-cyanoacrylic acid (LEG4) have successfully achieved outstanding efficiencies up to $14.30 \%$. In conclusion, DSSCs are indeed effective alternatives for the photovoltaics industries. Thus, there is still room for more distant improvement of these technologies.

\section{Funding}

This research was funded by the Ministry of Higher Education (MOHE), Malaysia, and Research Management and Innovation Centre (RMIC), Universiti Pendidikan Sultan Idris (UPSI). Grant number by MOHE is Fundamental Research Grant Scheme for Research Acculturation of Early Career Researchers-FRGS-RACER (code: 2019-0162-103-62 (RACER/1/2019/STG01/UPSI//4) and by RMIC, UPSI are University Research Grants-GPU (code: 2018-0143-101-01) and University Research Grants-GGPU (code: 2018-0080-106-01).

\section{Acknowledgments}

This research has no acknowledgment.

\section{Conflicts of Interest}

The authors declare no conflict of interest.

\section{References}

1. Smil, V. Energy and civilization: A history. MIT Press: Cambridge, England, 2018; pp. 1-568, https://doi.org/10.1353/tech.2018.0067.

2. Hanif, I.; Aziz, B.; Chaudhry, I.S. Carbon emissions across the spectrum of renewable and non-renewable energy use in developing economies of Asia. Renew Energy 2019, 143, 586-595, https://doi.org/10.1016/j.renene.2019.05.032.

3. Seyfouri, M.M.; Wang, D. Recent progress in bismuth ferrite-based thin films as a promising photovoltaic material. Crit Rev Solid State Mater Sci 2021, 46, 83-108, https://doi.org/10.1080/10408436.2019.1708700. 
4. Whiteman, A.; Rinke, T.; Esparrago, J.; Elsayed, S. Renewable capacity statistics 2016. International Renewable Energy Agency (IRENA), Abu Dhabi, United Arab Emirates, 2016; pp. 1-56.

5. Mhd Safri, N.A.; Zainuddin, Z.; Mohd Azmi, M.S.;Zulkifle, I.; Fudholi, A.; Ruslan, M.H.; Sopian, K. Current status of solar-assisted greenhouse drying systems for drying industry (food materials and agricultural crops). Trends in Food Science \& Technology 2021, 114, 633-657, https://doi.org/10.1016/j.tifs.2021.05.035.

6. Hidalgo, D.B.; Borges, R.J.; Nodal, Y.V. Applications of solar energy: History, sociology and last trends in investigation. Prod y Limpia 2018, 13, 21-28, https://doi.org/10.22507/pml.v13n2a3.

7. Liu, Z. What is the future of solar energy? Economic and policy barriers. Energy Sources, Part B Econ Plan Policy 2018, 13, 169-172, https://doi.org/10.1080/15567249.2017.1416704.

8. Guangul, F.M.; Chala, G.T. Solar energy as renewable energy source: SWOT analysis. 4th MEC Int Conf Big Data Smart City, ICBDSC 2019, 1-5, https://doi.org/10.1109/ICBDSC.2019.8645580.

9. Birel, Ö.; Nadeem, S.; Duman, H. Porphyrin-Based Dye-Sensitized Solar Cells (DSSCs): a Review. J Fluoresc 2017, 27, 1075-1085, https://doi.org/10.1007/s10895-017-2041-2.

10. Majid, Z.A.A.; Hazali, N.; Hanafiah, M.A.K.M.; Abdullah, A.A.; Ismail, A.F.; Ruslan, M.H.; Sopian, K.; Azmi, M.S.M. Design and Performance of 20 Watts Portable Solar Generator. IOP Conference Series: Materials Science and Engineering 2012, 36, https://doi.org/10.1088/1757-899X/36/1/012040.

11. Sharma, S.; Khan M.D.S.; Kumar Y.; Ranjan R. Conduction mechanism in rare earth-doped perovskite material through impedance analysis. Bull Mater Sci 2021, 44, https://doi.org/10.1007/s12034-021-02489-0.

12. Tsubomura, H.; Kobayashi, H. Solar Cells. Crit Rev Solid State Mater Sci 1993, 18, 261-326, https://doi.org/10.1080/10408439308242562.

13. Kumar, M.S.; Charanadhar, N.; Srikanth, V.V.S.S.; Rao, K.B.S.; Raj, B. Materials in harnessing solar power. Bull Mater Sci 2018, 41, https://doi.org/10.1007/s12034-018-1554-X.

14. Xiao, S.; Xu, S. High-efficiency silicon solar cells - Materials and devices physics. Crit Rev Solid State Mater Sci 2014, 39, 277-317, https://doi.org/10.1080/10408436.2013.834245.

15. Kemell, M.; Ritala, M.; Leskelä, M. Thin film deposition methods for CuInSe $\mathrm{Selar}_{2}$ cells. Crit Rev Solid State Mater Sci 2005, 30, 1-31, https://doi.org/10.1080/10408430590918341.

16. Tomar, N.; Agrawal, A.; Dhaka, V.S.; Surolia, P.K. Ruthenium complexes based dye sensitized solar cells: Fundamentals and research trends. Sol Energy 2020, 207, 59-76, https://doi.org/10.1016/j.solener.2020.06.060.

17. Hamed, M.S.G.; Mola, G.T. Mixed Halide Perovskite Solar Cells: Progress and Challenges. Crit Rev Solid State Mater Sci 2020, 45, 85-112, https://doi.org/10.1080/10408436.2018.1549976.

18. O'Regan, B.; Grätzel, M. A low-cost, high-efficiency solar cell based on dye-sensitized colloidal $\mathrm{TiO}_{2}$ films. Nature 1991, 353, 737-740, https://doi.org/10.1038/353737a0.

19. Carella, A.; Borbone, F.; Centore, R. Research progress on photosensitizers for DSSC. Front Chem 2018, 6 , 1-24, https://doi.org/10.3389/fchem.2018.00481.

20. Andualem, A.; Demiss, S. Review on Dye-Sensitized Solar Cells (DSSCs). J Heterocycl 2018, 1, 29-34, https://doi.org/10.33805/2639-6734.103.

21. Su'ait, M.S.; Rahman, M.Y.A.; Ahmad, A. Review on polymer electrolyte in dye-sensitized solar cells (DSSCs). Sol Energy 2015, 115, 452-470, https://doi.org/10.1016/j.solener.2015.02.043.

22. Mehmood, U.; Afzaal, M.; Al-Ahmed, A.; Yates, H.M.; Hakeem, A.S.; Ali, H.; Al-Sulaiman, F.A. Transparent Conductive Oxide Films for High-Performance Dye-Sensitized Solar Cells. IEEE Journal of Photovoltaics 2017, 7, 518-524, https://doi.org/10.1109/JPHOTOV.2016.2641303.

23. Sharma, K.; Sharma, V.; Sharma, S.S. Dye-Sensitized Solar Cells: Fundamentals and Current Status. Nanoscale Res Lett 2018, 13, https://doi.org/10.1186/s11671-018-2760-6.

24. Adedokun, O.; Titilope, K.; Awodugba, A.O. Review on Natural Dye-Sensitized Solar Cells (DSSCs). Int J Eng Technol 2016, 2, 34-41.

25. Chen, M.; Shao, L.L. Review on the recent progress of carbon counter electrodes for dye-sensitized solar cells. Chem Eng J 2016, 304, 629-45, https://doi.org/10.1016/j.cej.2016.07.001.

26. Longo, C.; De Paoli, M.A. Dye-Sensitized Solar Cells: A Successful Combination of Materials. J Braz Chem Soc 2003, 14, 889-901, https://doi.org/10.1590/S0103-50532003000600005.

27. Mehmood, U.; Rahman, S.U.; Harrabi, K.; Hussein, I.A.; Reddy, B.V.S. Recent advances in dye sensitized solar cells. Adv Mater Sci Eng 2014, 14, https://doi.org/10.1155/2014/974782.

28. Jiang, D.; Darabedian, N.; Ghazarian, S.; Hao, Y.; Zhgamadze, M.; Majaryan, N.; Shen, R.; Zhou, F. Dyes and Redox Couples with Matched Energy Levels: Elimination of the Dye-Regeneration Energy Loss in DyeSensitized Solar Cells. ChemPhysChem 2015, 16, 3385-3388, https://doi.org/10.1002/cphc.201500641.

29. Aghazada, S.; Nazeeruddin, M.K. Ruthenium complexes as sensitizers in dye-sensitized solar cells. Inorganics 2018, 6, https://doi.org/10.3390/inorganics6020052.

30. Ni, M.; Leung, M.K.H.; Leung, D.Y.C.; Sumathy, K. A review and recent developments in photocatalytic water-splitting using $\mathrm{TiO}_{2}$ for hydrogen production. Renew Sustain Energy Rev 2007, 11, 401-425, https://doi.org/10.1016/j.rser.2005.01.009.

31. Sahoo, D.D.; Roy, G.S. The Effects of Pt Doping on the Photo-reactivity of $\mathrm{TiO}_{2}$. Researcher 2013, 5, 104107. 
32. Nivea, R.; Gunasekaran, V.; Kannan, R.; Sakthivel, T.; Govindan, K. Enhanced photocatalytic efficacy of hetropolyacid pillared $\mathrm{TiO}_{2}$ nanocomposites. J Nanosci Nanotechnol 2014, 14, 4383-4386, https://doi.org/10.1166/jnn.2014.8655.

33. Cheung, S.H.; Nachimuthu, P; Joly, A.G.; Engelhard, M.H.; Bowman, M.K.; Chambers, S.A. N incorporation and electronic structure in N-doped $\mathrm{TiO}_{2}\left(\begin{array}{lll}1 & 1 & 0\end{array}\right)$ rutile. Surf Sci 2007, 601, 1754-1762, https://doi.org/10.1016/j.susc.2007.01.051.

34. Giribabu, L.; Kanaparthi, R.K.; Velkannan, V. Molecular engineering of sensitizers for dye-sensitized solar cell applications. Chem Rec 2012, 12, 306-328, https://doi.org/10.1002/tcr.201100044.

35. Zhang, S; Yang, X; Numata, Y; Han, L. Highly efficient dye-sensitized solar cells: Progress and future challenges. Energy Environ Sci 2013, 6, 1443-1464, https://doi.org/10.1039/c3ee24453a.

36. Yella, A.; Lee, H.-W.; Tsao Hoi, N.; Yi, C.; Chandiran Aravind, K.; Nazeeruddin, M.K.; Diau Eric, W.-G.; Yeh, C.-Y.; Zakeeruddin Shaik, M.; Grätzel, M. Porphyrin-Sensitized Solar Cells with Cobalt (II/III)-Based Redox Electrolyte Exceed 12 Percent Efficiency. Science (New York, N.Y.) 2011, 334, 629-634, https://doi.org/10.1126/science.1209688.

37. Lohar, G.M.; Rupnawar, D.V.; Shejawal, R.V.; Fulari, A.V. Preparation of natural dyes from salvia and spathodea for $\mathrm{TiO}_{2}$-based dye-sensitized solar cells (DSSCs) and their electrochemical impedance spectroscopic study under light and dark conditions. Bull Mater Sci 2020, 43, 1-8, https://doi.org/10.1007/s12034-020-02180-w.

38. Gómez-Ortíz, N.M.; Vázquez-Maldonado, I.A.; Pérez-Espadas, A.R.; Mena-Rejón, G.J.; Azamar Barrios, J.A.; Oskam, G. Dye-sensitized solar cells with natural dyes extracted from achiote seeds. Sol Energy Mater Sol Cells 2010, 94, 40-44, https://doi.org/10.1016/j.solmat.2009.05.013.

39. Al-Ghamdi, A.A.; Gupta, R.K.; Kahol, P.K.; Wageh, S.; Al-Turki, Y.A.; El Shirbeeny, W.; Yakuphanoglu, F. Improved solar efficiency by introducing graphene oxide in purple cabbage dye sensitized $\mathrm{TiO} 2$ based solar cell. Solid State Communications 2014, 183, 56-59, https://doi.org/10.1016/j.ssc.2013.12.021.

40. Kumara, N.T.R.N.; Ekanayake, P.; Lim, A.; Liew, L.Y.C.; Iskandar, M.; Ming, L.C.; Senadeera, G.K.R. Layered co-sensitization for enhancement of conversion efficiency of natural dye sensitized solar cells. Journal of Alloys and Compounds 2013, 581, 186-191, https://doi.org/10.1016/j.jallcom.2013.07.039.

41. Mariotti, N.; Bonomo, M.; Fagiolari, L.; Barbero, N.; Gerbaldi, C.; Bella, F.; Barolo, C. Recent advances in eco-friendly and cost-effective materials towards sustainable dye-sensitized solar cells. Green Chemistry 2020, 22, 7168-7218, https://doi.org/10.1039/d0gc01148g.

42. Semalti, P.; Sharma, S.N. Dye Sensitized Solar Cells (DSSCs) Electrolytes and Natural Photo-Sensitizers: A Review. J Nanosci Nanotechnol 2020, 20, 3647-3658, https://doi.org/10.1166/jnn.2020.17530.

43. Pandey, A.K.; Ahmad, M.S.; Abd Rahim, N.; Tyagi, V.V.; Saidur, R. Natural sensitizers and their applications in dye-sensitized solar cell. In: Environmental biotechnology: for sustainable future. 2nd ed.; Ranbir, C.S.; Naveen, K.A.; Richa, K. Eds.; Springer, Singapore, Volume 1, 2019; pp. 375-401, https://doi.org/10.1007/978-981-10-7284-0_15.

44. Alhorani, S.; Kumar, S.; Genwa, M.; Meena, P.L. Review of latest efficient sensitizer in dye-sensitized solar cells. AIP Conf Proc 2020, 2265, https://doi.org/10.1063/5.0017041.

45. Swapnil, P.; Meena, M.; Singh, S.K.; Dhuldhaj, U.P.; Harish; Marwal, A. Vital roles of carotenoids in plants and humans to deteriorate stress with its structure, biosynthesis, metabolic engineering and functional aspects. Curr Plant Biol 2021, 26, https://doi.org/10.1016/j.cpb.2021.100203.

46. Mezzomo, N.; Ferreira, S.R.S. Carotenoids functionality, sources, and processing by supercritical technology: A review. J Chem 2016, 2016, 1-16, https://doi.org/10.1155/2016/3164312.

47. Lee, J.J.; Crosby, K.M.; Pike, L.M.; Yoo, K.S.; Leskovar, D.I. Impact of genetic and environmental variation on development of flavonoids and carotenoids in pepper (Capsicum spp.). Sci Hortic (Amsterdam) 2005, 106, 341-352, https://doi.org/10.1016/j.scienta.2005.04.008.

48. Grotewold, E. The genetics and biochemistry of floral pigments. Annu Rev Plant Biol 2006, 57, 761-780, https://doi.org/10.1146/annurev.arplant.57.032905.105248.

49. van den Berg, H.; Faulks, R.; Granado, H.F.; Hirschberg, J.; Olmedilla, B.; Sandmann, G.; Southon, S.; Stahl, $\mathrm{W}$. The potential for the improvement of carotenoid levels in foods and the likely systemic effects. Journal of the Science of Food and Agriculture 2000, 80, 880-912, https://doi.org/10.1002/(SICI)10970010(20000515)80:7<880::AID-JSFA646>3.0.CO;2-1.

50. Narayan, M.R. Review: Dye sensitized solar cells based on natural photosensitizers. Renew Sustain Energy Rev 2012, 16, 208-215, https://doi.org/10.1016/j.rser.2011.07.148.

51. Gokilamani, N.; Muthukumarasamy, N.; Thambidurai, M.; Ranjitha, A.; Velauthapillai, D. Utilization of natural anthocyanin pigments as photosensitizers for dye-sensitized solar cells. J Sol-Gel Sci Technol 2013, 66, 212-219, https://doi.org/10.1007/s10971-013-2994-9.

52. Kumara, N.T.R.N.; Lim, A.; Lim, C.M.; Petra, M.I.; Ekanayake, P. Recent progress and utilization of natural pigments in dye sensitized solar cells: A review. Renew Sustain Energy Rev 2017, 78, 301-317, https://doi.org/10.1016/j.rser.2017.04.075.

53. Güzel, E.; Arslan, B.S.; Durmaz, V.; Cesur, M.; Tutar, Ö.F.; Sarı, T.; İşleyen, M.; Nebioğlu, M.; Şişman, İ. Photovoltaic performance and photostability of anthocyanins, isoquinoline alkaloids and betalains as natural sensitizers for DSSCs. Solar Energy 2018, 173, 34-41, https://doi.org/10.1016/j.solener.2018.07.048. 
54. Wendel, M.; Kumorkiewicz, A.; Wybraniec, S.; Ziółek, M.; Burdziński, G. Impact of $\mathrm{S}_{1} \rightarrow \mathrm{S}_{0}$ internal conversion in betalain-based dye sensitized solar cells. Dye Pigment 2017, 141, 306-315, https://doi.org/10.1016/j.dyepig.2017.02.026.

55. Panche, A.N.; Diwan, A.D.; Chandra, S.R. Flavonoids: An overview. J Nutr Sci 2016, 5, 1-15, https://doi.org/10.1017/jns.2016.41.

56. Ludin, N.A.; Al-Alwani Mahmoud, A.M.; Bakar Mohamad, A.; Kadhum, A.A.H.; Sopian, K.; Abdul Karim, N.S. Review on the development of natural dye photosensitizer for dye-sensitized solar cells. Renew Sustain Energy Rev 2014, 31, 386-396, https://doi.org/10.1016/j.rser.2013.12.001.

57. Aziz, N.; Mat Nor, N.A.; Arof, A.K. Optimization of anthocyanin extraction parameters from M. malabathricum via response surface methodology to produce natural sensitizer for dye sensitized solar cells. Opt Quantum Electron 2020, 52, https://doi.org/10.1007/s11082-019-2139-7.

58. Teoli, F.; Lucioli, S.; Nota, P.; Frattarelli, A.; Matteocci, F.; Carlo, A.D.; Caboni, E.; Forni, C. Role of pH and pigment concentration for natural dye-sensitized solar cells treated with anthocyanin extracts of common fruits. Journal of Photochemistry and Photobiology A: Chemistry 2016, 316, 24-30, https://doi.org/10.1016/j.jphotochem.2015.10.009.

59. Godibo, D.J.; Anshebo, S.T.; Anshebo, T.Y. Dye Sensitized Solar Cells Using Natural Pigments from Five Plants and Quasi-Solid State Electrolyte. J Braz Chem Soc 2015, 26, 92-101, https://doi.org/10.5935/01035053.20140218.

60. Al-Alwani, M.A.M.; Ludin, N.A.; Mohamad, A.B.; Kadhum, A.A.H.; Baabbad, M.M.; Sopian, K. Optimization of dye extraction from Cordyline fruticosa via response surface methodology to produce a natural sensitizer for dye-sensitized solar cells. Results Phys 2016, 6, 520-529, https://doi.org/10.1016/j.rinp.2016.08.013.

61. Suyitno, S.; Saputra, T.J.; Supriyanto, A.; Arifin, Z. Stability and efficiency of dye-sensitized solar cells based on papaya-leaf dye. Spectrochim Acta - Part A Mol Biomol Spectrosc 2015, 148, 99-104, https://doi.org/10.1016/j.saa.2015.03.107.

62. Swarnkar, A.K.; Sahare, S.; Chander, N.; Gangwar, R.K.; Bhoraskar, S. V.; Bhave, T.M. Nanocrystalline titanium dioxide sensitised with natural dyes for eco-friendly solar cell application. J Exp Nanosci 2015, 10, 1001-1011, https://doi.org/10.1080/17458080.2014.951410.

63. Taya, S.A.; El-Agez, T.M.; Elrefi, K.S.; Abdel-Latif, M.S. Dye-sensitized solar cells based on dyes extracted from dried plant leaves. Turkish J Phys 2015, 39, 24-30, https://doi.org/10.3906/fiz-1312-12.

64. abdel-latif, M.; Abuiriban, M.; Al-Dahoudi, N.; Al-Kahl, A.; Taya, S.; El-Agez, T.; Saleh, H. Dye-Sensitized Solar Cells Using Fifteen Natural Dyes as Sensitizers of Nanocrystalline TiO2. Science, Technology and Development 2015, 34, 135-139.

65. Maabong, K.; Muiva, C.M.; Monowe, P.; Sathiaraj, T.S.; Hopkins, M.; Nguyen, L.; et al. Natural pigments as photosensitizers for dye-sensitized solar cells with $\mathrm{TiO}_{2}$ thin films. Int J Renew Energy Res 2015, 5, 501506, https://doi.org/10.20508/ijrer.51907.

66. Shanmugam, V.; Manoharan, S.; Sharafali, A.; Anandan, S.; Murugan, R. Green grasses as light harvesters in dye sensitized solar cells. Spectrochim Acta - Part A Mol Biomol Spectrosc 2015, 135, 947-952, https://doi.org/10.1016/j.saa.2014.07.096.

67. Shalini, S.; Balasundara Prabhu, R.; Prasanna, S.; Mallick, T.K.; Senthilarasu, S. Review on natural dye sensitized solar cells: Operation, materials and methods. Renew Sustain Energy Rev 2015, 51, 1306-1325, https://doi.org/10.1016/j.rser.2015.07.052.

68. Biswas, A.K.; Barik, S.; Sen, A.; Das, A.; Ganguly, B. Design of efficient metal-free organic dyes having an azacyclazine scaffold as the donor fragment for dye-sensitized solar cells. J Phys Chem C 2014, 118, 2076320771, https://doi.org/10.1021/jp5049953.

69. Ye, M.; Wen, X.; Wang, M.; Iocozzia, J.; Zhang, N.; Lin, C.; Lin, Z. Recent advances in dye-sensitized solar cells: from photoanodes, sensitizers and electrolytes to counter electrodes. Materials Today 2015, 18, 155162, https://doi.org/10.1016/j.mattod.2014.09.001.

70. Al-Eid, M.; Lim, S.; Park, K.-W.; Fitzpatrick, B.; Han, C.-H.; Kwak, K.; Hong, J.; Cooke, G. Facile synthesis of metal-free organic dyes featuring a thienylethynyl spacer for dye sensitized solar cells. Dyes and Pigments 2014, 104, 197-203, https://doi.org/10.1016/j.dyepig.2014.01.004.

71. Błaszczyk, A. Strategies to improve the performance of metal-free dye-sensitized solar cells. Dye Pigment 2018, 149, 707-718, https://doi.org/10.1016/j.dyepig.2017.11.045.

72. Krawczak, E. Dye Photosensitizers and Their Influence on Dssc Efficiency: a Review. Inform Autom Pomiary w Gospod i Ochr Środowiska 2019, 9, 86-90, https://doi.org/10.35784/iapgos.34.

73. Saini, R.K.; Kadyan, P.S.; Singh, J.; Bhagwan, S.; Singh, D. Fabrication and Photovoltaic Characteristics of Alizarin Dye Based DSSCs. Der Pharma Chem 2019, 11, 43-48.

74. Kakiage, K.; Aoyama, Y.; Yano, T.; Oya, K.; Fujisawa, J.I.; Hanaya, M. Highly-efficient dye-sensitized solar cells with collaborative sensitization by silyl-anchor and carboxy-anchor dyes. Chem Commun 2015, 51, 15894-15897, https://doi.org/10.1039/c5cc06759f.

75. Saputri, D.G.; Ramelan, A.H.; Sayekti, W.; Nurosyid, F.; Ramadhani, F.; Supriyanto, A. Effect of LEG4 concentration as a sensitizer on increasing efficiency in DSSC-based solar cells. AIP Conf Proc 2020, 2296, https://doi.org/10.1063/5.0030849. 
76. Siva Kumar, G.; Srinivas, K.; Shanigaram, B.; Bharath, D.; Singh, S.P.; Bhanuprakash, K.; Rao, V.J.; Islam, A.; Han, L. Metalfree organic dyes containing thiadiazole unit for dye-sensitized solar cells: A combined experimental and theoretical study. $R S C A d v$ 2014, 4, 13172-13181, https://doi.org/10.1039/c3ra47330a.

77. Ganesan, S.; Muthuraaman, B.; Mathew, V.; Madhavan, J.; Maruthamuthu, P.; Austin Suthanthiraraj, S. Performance of a new polymer electrolyte incorporated with diphenylamine in nanocrystalline dye-sensitized solar cell. Sol Energy Mater Sol Cells 2008, 92, 1718-1722, https://doi.org/10.1016/j.solmat.2008.08.004.

78. Lin, H.; Bai, F. Electronic process in organic solids. In: Organic Optoelectronics. 2nd ed.; Hu, W.; Eds.; Publlisher: Wiley-VCH Verlag GMBh \& Co. KGaA, Germany, First Edition, 2013; pp. 1-42, https://doi.org/10.1002/9783527653454.ch1.

79. Kuciauskas, D.; Monat, J.E.; Villahermosa, R.; Gray, H.B.; Lewis, N.S.; McCusker, J.K. Transient absorption spectroscopy of ruthenium and osmium polypyridyl complexes adsorbed onto nanocrystalline $\mathrm{TiO}_{2}$ photoelectrodes. J Phys Chem B 2002, 106, 9347-9358, https://doi.org/10.1021/jp014589f.

80. Nazeeruddin, M.K.; Kay, A.; Rodicio, I.; Humphry-Baker, R.; Mueller, E.; Liska, P.; Vlachopoulos, N.; Graetzel, M. Conversion of light to electricity by cis-X2bis(2,2'-bipyridyl-4,4'-dicarboxylate)ruthenium(II) charge-transfer sensitizers ( $\mathrm{X}=\mathrm{Cl}-, \mathrm{Br}-, \mathrm{I}-, \mathrm{CN}-$, and $\mathrm{SCN}-$ ) on nanocrystalline titanium dioxide electrodes. Journal of the American Chemical Society 1993, 115, 6382-6390, https://doi.org/10.1021/ja00067a063.

81. Wang, P.; Zakeeruddin, S.M.; Moser, J.E.; Humphry-Baker, R.; Comte, P.; Aranyos, V.; et al. Stable new sensitizer with improved light harvesting for nanocrystalline dye-sensitized solar cells. Adv Mater 2004, 16, 1806-1811, https://doi.org/10.1002/adma.200400039.

82. Buscaino, R.; Baiocchi, C.; Barolo, C.; Medana, C.; Grätzel, M.; Nazeeruddin, M.K.; Viscardi, G. A mass spectrometric analysis of sensitizer solution used for dye-sensitized solar cell. Inorganica Chimica Acta 2008, 361, 798-805, https://doi.org/10.1016/j.ica.2007.07.016.

83. Nazeeruddin, M.K.; Péchy, P.; Renouard, T.; Zakeeruddin, S.M.; Humphry-Baker, R.; Comte, P.; Liska, P.; Cevey, L.; Costa, E.; Shklover, V.; Spiccia, L.; Deacon, G.B.; Bignozzi, C.A.; Grätzel, M. Engineering of Efficient Panchromatic Sensitizers for Nanocrystalline TiO2-Based Solar Cells. Journal of the American Chemical Society 2001, 123, 1613-1624, https://doi.org/10.1021/ja003299u.

84. Tsaturyan, A.A.; Shcherbakov, I.N.; Shvydko, T.V.; Kogan, V.A. Iron(II) and ruthenium(II) complexes with polypyridine derivatives as sensitizers for DSSC: the structure and spectral properties, as studied by quantum chemistry methods. Russian Chemical Bulletin 2017, 66, 23-29, https://doi.org/10.1007/s11172-017-1694-y.

85. Wang, P.; Zakeeruddin, S.M.; Comte, P.; Charvet, R.; Humphry-Baker, R.; Grätzel, M. Enhance the Performance of Dye-Sensitized Solar Cells by Co-grafting Amphiphilic Sensitizer and Hexadecylmalonic Acid on TiO2 Nanocrystals. The Journal of Physical Chemistry B 2003, 107, 14336-14341, https://doi.org/10.1021/jp0365965.

86. Kuang, D.; Klein, C.; Snaith, H.J.; Moser, J.-E.; Humphry-Baker, R.; Comte, P.; Zakeeruddin, S.M.; Grätzel, M. Ion Coordinating Sensitizer for High Efficiency Mesoscopic Dye-Sensitized Solar Cells: Influence of Lithium Ions on the Photovoltaic Performance of Liquid and Solid-State Cells. Nano Letters 2006, 6, 769773, https://doi.org/10.1021/n1060075m.

87. Kuang, D.; Klein, C.; Ito, S.; Moser, J.E.; Humphry-Baker, R.; Zakeeruddin, S.M.; Grätzel, M. High Molar Extinction Coefficient Ion-Coordinating Ruthenium Sensitizer for Efficient and Stable Mesoscopic DyeSensitized Solar Cells. Advanced Functional Materials 2007, 17, 154-160, https://doi.org/10.1002/adfm.200600483.

88. Chen, C-Y.; Wu, S-J.; Wu, C-G.; Chen, J-G.; Ho, K-C. A Ruthenium Complex with Superhigh LightHarvesting Capacity for Dye-Sensitized Solar Cells. Angew Chemie 2006, 45, 5822-5825, https://doi.org/10.1002/anie.200601463.

89. Chen, C.-Y.; Wang, M.; Li, J.-Y.; Pootrakulchote, N.; Alibabaei, L.; Ngoc-le, C.-h.; Decoppet, J.-D.; Tsai, J.-H.; Grätzel, C.; Wu, C.-G.; Zakeeruddin, S.M.; Grätzel, M. Highly Efficient Light-Harvesting Ruthenium Sensitizer for Thin-Film Dye-Sensitized Solar Cells. ACS Nano 2009, 3, 3103-3109, https://doi.org/10.1021/nn900756s.

90. Sauvage, F.; Decoppet, J.-D.; Zhang, M.; Zakeeruddin, S.M.; Comte, P.; Nazeeruddin, M.; Wang, P.; Grätzel, M. Effect of Sensitizer Adsorption Temperature on the Performance of Dye-Sensitized Solar Cells. Journal of the American Chemical Society 2011, 133, 9304-9310, https://doi.org/10.1021/ja110541t.

91. Cao, Y.; Bai, Y.; Yu, Q.; Cheng, Y.; Liu, S.; Shi, D.; Gao, F.; Wang, P. Dye-Sensitized Solar Cells with a High Absorptivity Ruthenium Sensitizer Featuring a 2-(Hexylthio)thiophene Conjugated Bipyridine. The Journal of Physical Chemistry C 2009, 113, 6290-6297, https://doi.org/10.1021/jp9006872.

92. Cebeci, C.; Arslan, B.S.; Güzel, E.; Nebioğlu, M.; Şişman, İ.; Erden, İ. 4,5-Diazafluorene ligands and their ruthenium(II) complexes with boronic acid and catechol anchoring groups: design, synthesis and dyesensitized solar cell applications. J Coord Chem 2021, 74, 1366-1381, https://doi.org/10.1080/00958972.2021.1914332.

93. Chen, W.-C.; Kong, F.-T.; Li, Z.-Q.; Pan, J.-H.; Liu, X.-P.; Guo, F.-L.; Zhou, L.; Huang, Y.; Yu, T.; Dai, S.Y. Superior Light-Harvesting Heteroleptic Ruthenium(II) Complexes with Electron-Donating Antennas for High Performance Dye-Sensitized Solar Cells. ACS Applied Materials \& Interfaces 2016, 8, 19410-19417, https://doi.org/10.1021/acsami.6b04411. 
94. Malzner, F.J. Catch the Sun : New Ancillary Ligands in Copper ( I ) Dye-Sensitized Solar Cells Lead to Panchromatic Light Harvesting. Doctoral Thesis, University of Basel, Switzerland, 22 Aug 2018, https://doi.org/10.5451/unibas-006823315.

95. Fürer, S.O.; Bozic-Weber, B.; Schefer, T.; Wobill, C.; Constable, E.C.; Housecroft, C.E.; Willgert, M. Understanding why replacing I3-/I- by cobalt(ii)/(iii) electrolytes in bis(diimine)copper(i)-based dyesensitized solar cells improves performance. Journal of Materials Chemistry A 2016, 4, 12995-13004, https://doi.org/10.1039/c6ta04879j.

96. Dragonetti, C.; Magni, M.; Colombo, A.; Melchiorre, F.; Biagini, P.; Roberto, D. Coupling of a copper dye with a copper electrolyte: A fascinating springboard for sustainable dye-Sensitized solar cells. ACS Appl Mater Interfaces 2018, 1, 751-756, https://doi.org/10.1021/acsaem.7b00196.

97. Wang, Z.S.; Cui, Y.; Hara, K.; Dan-Oh, Y.; Kasada, C.; Shinpo, A. A high-light-harvesting-efficiency coumarin dye for stable dye-sensitized solar cells. Adv Mater 2007, 19, 1138-1141, https://doi.org/10.1002/adma.200601020.

98. Mishra, A.; Fischer, M.K.R.; Büuerle, P. Metal-Free organic dyes for dye-Sensitized solar cells: From structure: Property relationships to design rules. Angew Chemie - Int Ed 2009, 48, 2474-2499, https://doi.org/10.1002/anie.200804709.

99. Jung, I.; Jae, K.L.; Kyu, H.S.; Song, K.; Sang, O.K.; Ko, J. Synthesis and photovoltaic properties of efficient organic dyes containing the benzo[b]furan moiety for solar cells. J Org Chem 2007, 72, 3652-3658, https://doi.org/10.1021/jo0625150.

100.Mathews, L.D.; Tidwell, C.P.; Bharara, P.; Stephens, G.; Su, T.Y.; Carter, A. Copper 5,10,15,20-Tetrakis(3,4dibenzyloxyphenyl) porphyrin. Molbank 2017, 2017, 3-6, https://doi.org/10.3390/M931.

101. Mustafar, S.; Wu, K.-H.; Toyoda, R.; Takada, K.; Maeda, H.; Miyachi, M.; Sakamoto, R.; Nishihara, H. Electrochemical fabrication of one-dimensional porphyrinic wires on electrodes. Inorganic Chemistry Frontiers 2016, 3, 370-375, https://doi.org/10.1039/c5qi00239g.

102. Mustafar, S.; Abbas, N.M.; Juahir, Y.; Ali, N.M.; Hashim, N.; Sharif, A.M. Characterisation of porphyrinic nanowires on three different solid substrates. Int J Nanoelectron Mater 2020, 13, 373-80.

103.Suzaliza, M.; Norliana, M.A.; Lee, Y.L.; Norhayati, H.; Illyas, M.I. A glance on immobilisation of porphyrins on solid support and potential future research. AIP Conf Proc 2018, 2030, https://doi.org/10.1063/1.5066741.

104.Nasirian, A.; Mirkhani, V.; Moghadam, M.; Tangestaninejad, S.; Mohammadpour-Baltork, I. Efficient dyesensitized solar cell based on a new porphyrin complex as an inorganic photosensitizer. J Chem Sci 2020, 132, 1-8, https://doi.org/10.1007/s12039-020-01781-6.

105. Arteaga, D.; Cotta, R.; Ortiz, A.; Insuasty, B.; Martin, N.; Echegoyen, L. Zn(II)-porphyrin dyes with several electron acceptor groups linked by vinyl-fluorene or vinyl-thiophene spacers for dye-sensitized solar cells. Dye Pigment 2015, 112, 127-137, https://doi.org/10.1016/j.dyepig.2014.06.028.

106.Zhang, W.; Alonso-Mori, R.; Bergmann, U.; Bressler, C.; Chollet, M.; Galler, A.; Gawelda, W.; Hadt, R.G.; Hartsock, R.W.; Kroll, T.; Kjær, K.S.; Kubiček, K.; Lemke, H.T.; Liang, H.W.; Meyer, D.A.; Nielsen, M.M.; Purser, C.; Robinson, J.S.; Solomon, E.I.; Sun, Z.; Sokaras, D.; van Driel, T.B.; Vankó, G.; Weng, T.-C.; Zhu, D.; Gaffney, K.J. Tracking excited-state charge and spin dynamics in iron coordination complexes. Nature 2014, 509, 345-348, https://doi.org/10.1038/nature13252.

107.Jakubikova, E.; Bowman, D.N. Fe(II)-polypyridines as chromophores in dye-sensitized solar cells: A computational perspective. Acc Chem Res 2015, 48, 1441-1449, https://doi.org/10.1021/ar500428t.

108. Auböck, G.; Chergui, M. Sub-50-fs photoinduced spin crossover in $\left[\mathrm{Fe}(\mathrm{bpy})_{3}\right]^{2+}$. Nat Chem 2015, 7, 629633, https://doi.org/10.1038/nchem.2305.

109. Meyer, T.J. Photochemistry Of Metal Coordination Complexes: Metal To Ligand Charge Transfer Excited States. Pure Appl Chem 1986, 58, 1193-1206, https://doi.org/10.1351/pac198658091193.

110. Consani, C.; Prémont-Schwarz, M.; ElNahhas, A.; Bressler, C.; van Mourik, F.; Cannizzo, A.; Chergui, M. Vibrational Coherences and Relaxation in the High-Spin State of Aqueous [FeII(bpy)3]2+ Angewandte Chemie International Edition 2009, 48, 7184-7187, https://doi.org/10.1002/anie.200902728.

111. Mishra, R. Recent Developments in Copper and Iron Based Dyes as Light Harvesters. In: Advances in Water Pollution Monitoring and Control. 2nd ed.; Siddiqui N.A.; Tauseef, S.M.; Dobhal R.; Eds.; Springer: Singapore, First Edition, 2020; pp. 107-114, https://doi.org/10.1007/978-981-32-9956-6_12.

112. Ferrere, S.; Gregg, B.A. Photosensitization of $\mathrm{TiO}_{2}$ by [Fe(II)(2,2'-bipyridine-4,4'-dicarboxylic acid $\left.)_{2}(\mathrm{CN})_{2}\right]$ : Band selective electron injection from ultra-short-lived excited states. J Am Chem Soc 1998, 120, 843-844, https://doi.org/10.1021/ja973504e.

113.Harlang, T.C.B.; Liu, Y.; Gordivska, O.; Fredin, L.A.; Ponseca, C.S.; Huang, P.; Chábera, P.; Kjaer, K.S.; Mateos, H.; Uhlig, J.; Lomoth, R.; Wallenberg, R.; Styring, S.; Persson, P.; Sundström, V.; Wärnmark, K. Iron sensitizer converts light to electrons with $92 \%$ yield. Nature Chemistry 2015, 7, 883-889, https://doi.org/10.1038/nchem.2365.

114.Fredin, L.A.; Pápai, M.; Rozsályi, E.; Vankó, G.; Wärnmark, K.; Sundström, V.; Persson, P. Exceptional Excited-State Lifetime of an Iron(II)-N-Heterocyclic Carbene Complex Explained. The Journal of Physical Chemistry Letters 2014, 5, 2066-2071, https://doi.org/10.1021/jz500829w.

115.Liu, Y.; Persson, P.; Sundström, V.; Wärnmark, K. Fe N-Heterocyclic Carbene Complexes as Promising Photosensitizers. Acc Chem Res 2016, 49, 1477-1485, https://doi.org/10.1021/acs.accounts.6b00186. 
116.Duchanois, T.; Liu, L.; Pastore, M.; Monari, A.; Cebrián, C.; Trolez, Y.; Darari, M.; Magra, K.; FrancésMonerris, A.; Domenichini, E.; Beley, M.; Assfeld, X.; Haacke, S.; Gros, P.C. NHC-Based Iron Sensitizers for DSSCs. Inorganics 2018, 6, 63-89, https://doi.org/10.3390/inorganics6020063.

117. Çakar, S.; Özacar, M. The effect of iron complexes of quercetin on dye-sensitized solar cell efficiency. $J$ Photochem Photobiol A Chem 2017, 346, 512-522, https://doi.org/10.1016/j.jphotochem.2017.07.006.

118. Chenab, K.K.; Sohrabi, B.; Meymian, M.Z.; Mousavi, S.V. Naphthoquinone derivative-based dye for dyesensitized solar cells: Experimental and computational aspects. Mater Res Express 2019, 6, https://doi.org/10.1088/2053-1591/ab2500.

119. Khanmohammadi, K.; Sohrabi, B.; Meymian, M.Z. Effect of electron-donating and -withdrawing substitutions in naphthoquinone sensitizers: The structure engineering of dyes for DSSCs. J Mol Struct 2018, 1167, 274-279, https://doi.org/10.1016/j.molstruc.2018.05.014.

120.Baldenebro-López, J.; Castorena-González, J.; Flores-Holguín, N.; Almaral-Sánchez, J.; Glossman Mitnik, D. Computational molecular nanoscience study of the properties of copper complexes for dyesensitized solar cells. Int J Mol Sci 2012, 13, 16005-16019, https://doi.org/10.3390/ijms131216005.

121.Chenab, K.K.; Sohrabi, B.; Meymian, M.Z. Cobalt complex dye as a novel sensitizer in dye sensitized solar cells. Mater Res Express 2020, 6, https://doi.org/10.1088/2053-1591/ab61c0. 